Sławiński Mirosław A., Jarosz Piotr M., Jasielski Patryk, Zarobkiewicz Michał K., Wawryk-Gawda Ewelina, Jodłowska-Jęrych Barbara. The awareness of Polish society about bee pollen and its health-promoting properties - preliminary assessment of factors determined bee pollen supplementation in survey-based study. Journal of Education, Health and Sport. 2020;10(9):820-829. eISSN 2391-8306. DOI http://dx.doi.org/10.12775/JEHS.2020.10.09.099

https://apcz.umk.pl/czasopisma/index.php/JEHS/article/view/JEHS.2020.10.09.099

https://zenodo.org/record/4053747

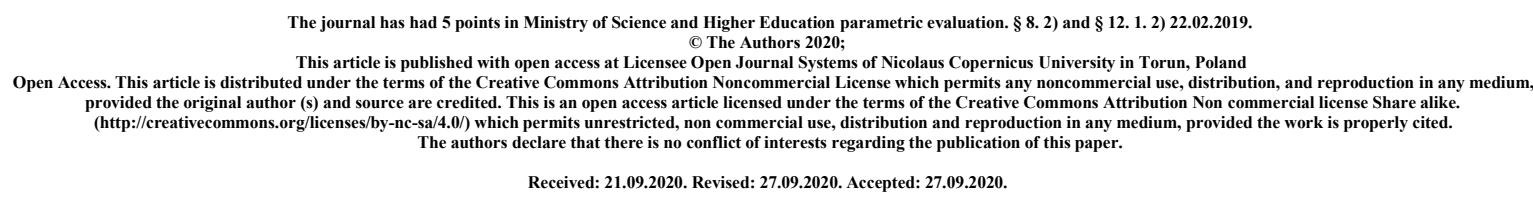

The awareness of Polish society about bee pollen and its health-promoting properties preliminary assessment of factors determined bee pollen supplementation in surveybased study

Mirosław A. Sławiński [1], Piotr M. Jarosz [1], Patryk Jasielski [1], Michał K. Zarobkiewicz [1], Ewelina Wawryk-Gawda [1], Barbara Jodłowska-Jędrych [1]

Mirosław A. Sławiński: miroslaw.slawinski92@gmail.com; ORCID: 0000-0001-8025-4745

Piotr M. Jarosz; pjarosz196@gmail.com; ORCID: 0000-0003-0489-2600; Patryk Jasielski; patryk.jasielski111@gmail.com. ORCID: 0000-0002-0958-735X Michał K. Zarobkiewicz; michal.zarobkiewicz@umlub.pl; ORCID: 0000-0003-0788-6353 Ewelina Wawryk-Gawda; ewelina.wawryk-gawda@umlub.pl; ORCID: 0000-0001-69146735

Barbara Jodłowska-Jędrych; barbara.jodlowska-jedrych@umlub.pl; ORCID: 0000-0003$3483-8752$

\title{
Affiliations:
}

1. Chair and Department of Histology and Embryology with Experimental Cytology Unit, Medical University of Lublin, Radziwiłłowska Street 11, 20-080 Lublin, Poland

\begin{abstract}
:
Introduction: The apiculture is an old and long-established craft. Bee pollen is a flower pollen packed by bees and used as a food source for a hive. Mainly, it consists of simple sugars, protein, fatty acid but also minerals and vitamins. Bee pollen has multiple properties: antioxidative, antineoplastic, antibacterial and much more. It is commonly used by herbalists in treatment of certain medical conditions. Nevertheless, it is unsure whether bee pollen has any health benefits.
\end{abstract}

Purpose: The aim of our study was to assess initially a knowledge of respondents about bee pollen and find out which factors can determine bee pollen supplementation. 
Materials and methods: The study was based on an on-line questionnaire, which was created by using Google Forms tool. It consisted of 27 both open and closed questions. Anonymity and resignation opportunity were warranted. The statistical analysis based on questionnaires were elaborated by using $\mathrm{R}$ custom script.The Pearson Chi-square test was applied to investigate the relationship between bee pollen usage and: (a) gender, (b) body mass index (BMI) and (c) living area.

Results: The study was based on questionnaires given to 511 respondents, 153 of them were represented by men, whereas 358 by women. The 403 respondents gathered what was bee pollen. Bee pollen has been used by 123 persons (24\% of respondents). Majority of respondents knew what bee pollen is. However, only one third of this group already used this product in their diet. People who took bee pollen had awareness about the advantages of this dietary supplement. Interestingly, Chi-square test analysis showed that the relationship between bee pollen usage and gender, as well as bee pollen usage and BMI is statistically significant. Contrary, there is no relationship between bee pollen and living area.

Conclusions: Our study has highlighted the issue of this problem area among polish society. Quarter of respondents have ever used bee pollen as a part of their diet. Current results show that polish society has been able to have the knowledge about its beneficial properties, because of their declaration submitted to our survey.

Key words: bee pollen; survey; health; dietary supplement;

\section{Historical overview}

The Apiculture is a historical craft. According to the evidence-based studies humans began collecting honey roughly 9000 years ago. Bees products were used as a medicament. Evidence is retained in Egyptian art and papyruses. [1] Beekeeping is constantly important in medicine and as a component of the healthy human diet and apitherapy as well. The use of the products of bee raising in medicine; thus, current studies constantly highlight the usefulness of apitherapy products for medicinal use including: ophthalmology, lung diseases, menopausal problems. In addition, the honey is mentioned in literature as a novel weapon against cancer. [1-5]

\section{Bee pollen}

Bee pollen is also called "bee bread", or "ambrosia"; it is stored in brood cells, mixed with saliva, and sealed with a drop of honey. [6] Bee pollen contains vitamins, minerals, carbohydrates, lipids, and protein. [7] The specific composition of bee pollen ascribes a wide spectrum of medical properties, e.g.: antioxidative [8], bactericidal [9], antineoplastic [10], and immunostimulant activity [11]. Bee products are offered to persons suffering from protein-energy malnutrition caused by cancer and lung problems [3,4]. They are used as supplements and are touted by herbalists as a treatment for a variety of medical conditions [11-16]. Besides that, health awareness is currently increasing, hence people should be educated about dietary supplements which are taken more commonly.

\section{Purpose:}

The aim of our study was to assess initially a knowledge of respondents about bee pollen and find out which factors can determine bee pollen supplementation. 


\section{Material and methods:}

The study was based on an on-line questionnaire, which was created by using Google Forms tool. This method enabled personalization of survey - a subsequent question was dependent on the given previous answer. As an example: if the respondent displayed lack of knowledge about bee pollen, the survey circumvents questions about apiculture and participants had to respond on general questions, non-associated with the apiculture. Questionnaire consisted of 27 both open and closed questions. Anonymity and resignation opportunity were warranted.

\section{Participant recruitment}

The survey was presented on the internet, inclusive of social media. According to the report "Digital in 2017 Global Overview", created by We Are Social \& Hootsuite, Facebook is visited every day by $2 / 3$ of polish internet users. Thanks for this method, reaching a variety of social groups was easily possible.

\section{Statistical analysis}

The statistical analysis based on questionnaires were based on custom $\mathrm{R}$ script. Particularly, the Pearson Chi-square test was applied to investigate the relationship between bee pollen usage and: (a) gender, (b) body mass index (BMI) and (c) living area. The Cramer's V test was calculated to assess the effect size.

\section{Results}

The study was based on questionnaires given to 511 respondents, $31 \%$ of them were represented by men, whereas $69 \%$ by women. Examined people were between 16 and 66 years old. The age median for women was 23 with interquartile range (IQR) equals 3 . The age median for men was 23 years old with IQR equals 6 (Fig.1). 


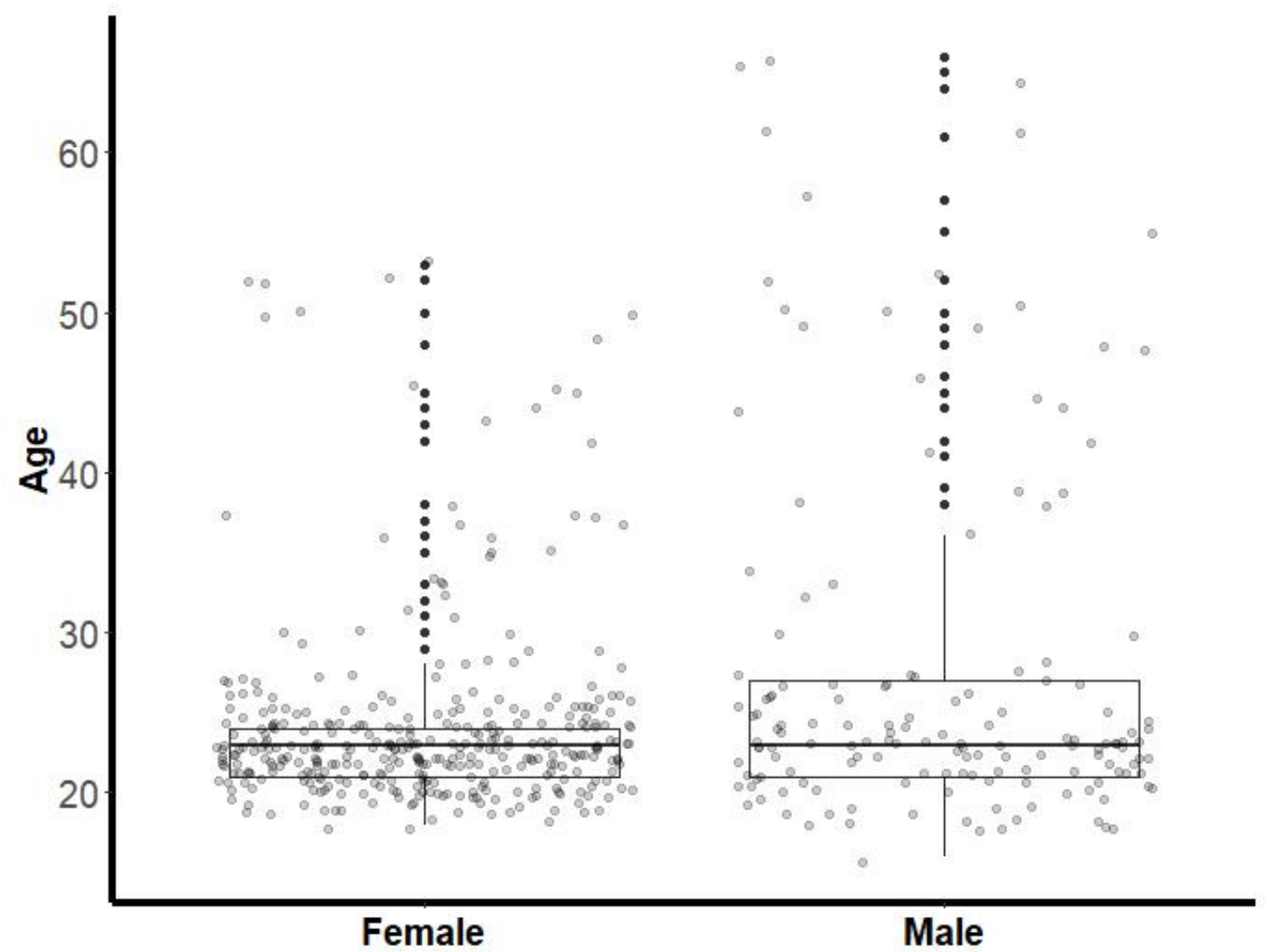

Fig. 1 The correlation between sex and age among respondents 
The median body height for women was equal to $59 \mathrm{~kg}(\mathrm{IQR}=12)$. Whereas, the median body height for men was equal $78 \mathrm{~kg}(\mathrm{IQR}=15)$ (Fig.2).

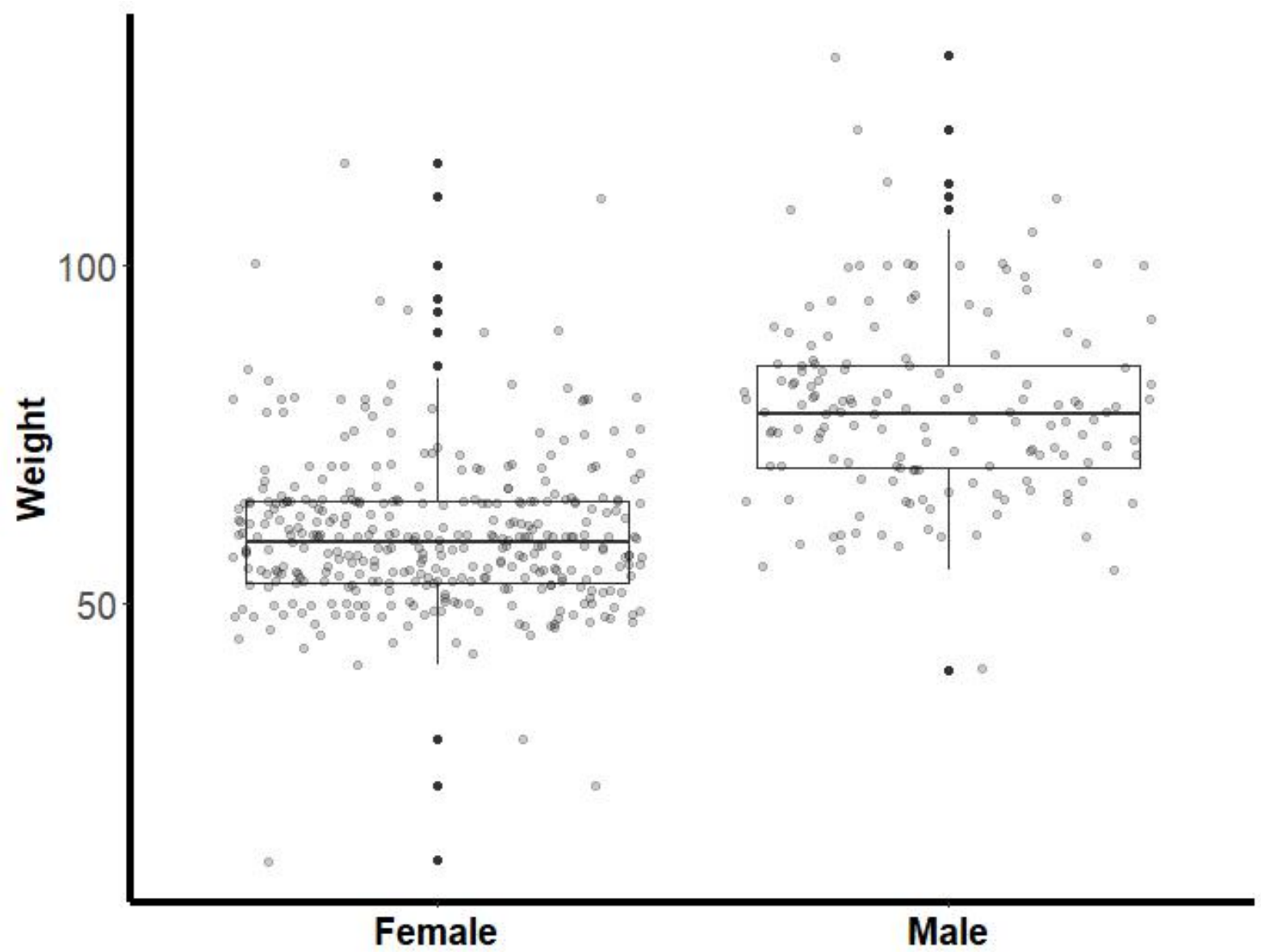

Fig. 2 The correlation between sex and body weight among respondents 
Within the analyzed group $(\mathrm{n}=511)$ the bee pollen has been used by 123 people $(25 \%$ of respondents). The most common cause was friend recommendation. The group of health care was represented only by 5 doctors and 6 dieticians. Interestingly, there is a relation between bee pollen usage and gender. However, the result of Cramer's V test $(\mathrm{df}=1)$ equal 0.102 suggests that it is a weak relationship. Within the men group more people used bee pollen than within the women group (Fig 3).

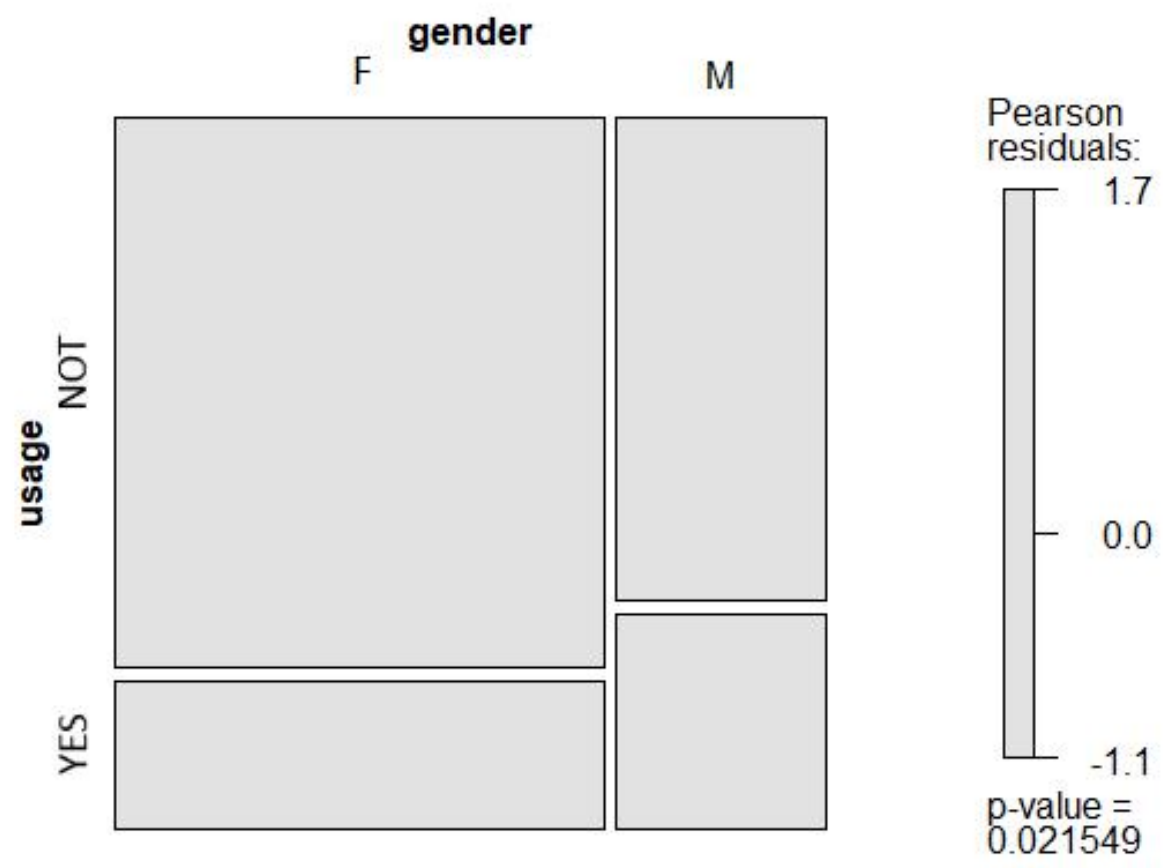

Fig. 3 The correlation between gender and usage of bee pollen among respondents 
The analysis of Chi-squared test suggests that there is significant relation between BMI and usage of bee pollen. However, it is not a strong relationship (Cramer's V (df=3): 0.143) (Fig. 4).

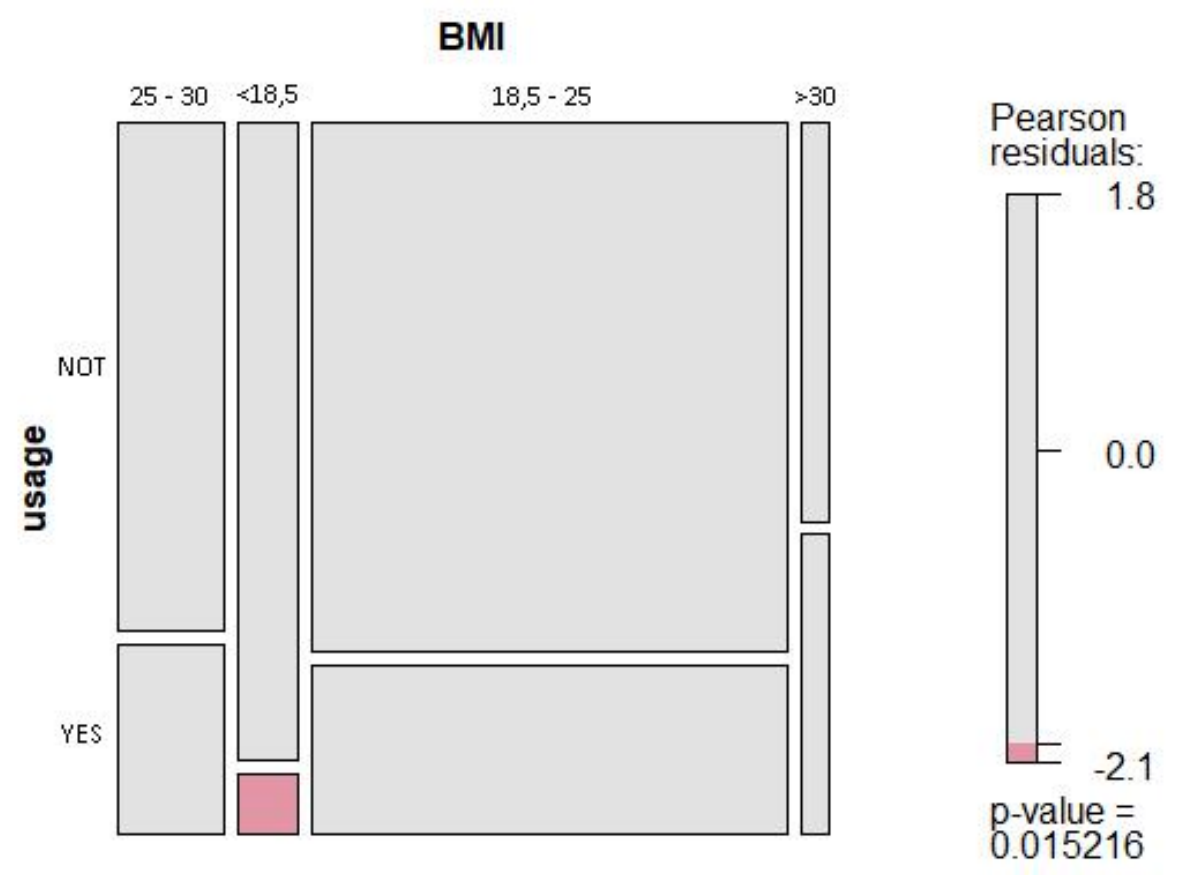

Fig. 4 The correlation between BMI and usage of bee pollen among respondents

Among 511 examined people, 407 respondents gathered what is bee pollen. $82,39 \%$ of people thought that bee pollen is collected by bees.

Only $48 \%$ of respondents have ever had an opportunity to buy bee pollen. Most frequently it was bought from apiculturists $(52,55 \%)$. Similarly, people bought bee pollen in health food stores or shops with apian products $-42,75$ and $43,55 \%$, respectively. 


\section{Discussion:}

The number of participants who took part in the study was 511. Awareness of society about healthy lifestyle and nutrient food is highlighted in social media and dietary trends. It is constantly growing, and attention on apian products as well. Nowadays, products created by bees are commonly used in medicine - in apitherapy - e. g., wound treatment; moreover, in unconventional treatment. The main purpose of this research was to initially assess basic knowledge about bee pollen in polish society. Our study suggests that interest in bee pollen among polish population is constantly increasing.

Why should scientists take under consideration research about bee pollen? Mainly, because pollen contains approximately 200 substances which can be analyzed and together used for new purposes. Flavonoids are a valuable source of new knowledge [17]. Further research can help to discover remedy, which is hidden in hives and plants.

The essential question is, whether bee pollen intake is safe. Every single comestible product may induce adverse effects as well bee bread. Current studies mention that bee pollen contains substances which are risk factors and culprits in allergies occurrence. According to literature, bee pollen can cause renal failure among liable persons [12]. Eosinophilic gastroenteropathy due to pollen intake was reported by some consumers $[13,14]$. Thus, potential consumers should wonder and elaborate knowledge about bee pollen before adding it to one's diet. This fact is so relevant due to widespread availability of bee pollen including: apiculturists, health food stores, markets or shops with apian products, which were mentioned by respondents in our study.

Thanks to the advantages of this product, bee pollen presents a wide scope of usage in medicine $[4,9]$. In our study, the interviewees, who have ever eaten pollen, had a good knowledge about beneficial features of pollen. Intake was unequivocally correlated with avail for their health, hence health properties are probably known to the majority of respondents. Further analysis might explain potential correlations between intake and knowledge about bee pollen beneficial properties.

Embrace of bee pollen is not only an act of prophylaxis, but also can be useful in cancer treatment due to anti-oncogenic substances included in pollen [15,16]. According to data, this product can support production of drugs which are used in treatment of neoplasms. [3]

Due to many benefits for the body, intake of the bee pollen is valuable. According to literature, pollen can have avails for the health of men with prostatic gland diseases [18]. Pollen decreases the level of cholesterol. Moreover, pollen is antioxidant, which also encourages usage of this product.

Our study shed a light on knowledge about bee pollen and its health-promoting properties among polish society from a variety of social backgrounds and factors which can determine it. Based on the PubMed database searching, we have found none of the studies dealt with similar issues; thus our research seems to be more interesting for scientists. The aim of this manuscript is also an invitation to a meeting to discuss the current state of knowledge and to compare similar studies. The topic about bee pollen presents a wide scope of unexplored possibilities. 
Conclusions: Our study allows us to venture a guess that interviewees supplemented bee pollen have had proper knowledge about its beneficial properties. Vast majority of our survey respondents know what bee pollen is. Quarter have ever used it as a part of their diet. Plurality of interviewee claimed that they received health benefits from pollen intake. According to results, polish society has awareness about bee pollen and its health-promoting properties. Further analysis might explain potential correlations between intake and knowledge about bee pollen beneficial properties.

\section{References}

1. Fratellone PM, Tsimis F, Fratellone G. Apitherapy Products for Medicinal Use. J Altern Complement Med. 2016 Dec;22(12):1020-2.

2. Münstedt K, Männle H. Apitherapy for menopausal problems [published online ahead

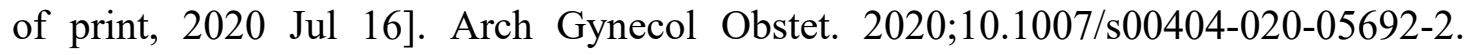
doi:10.1007/s00404-020-05692-2

3. Badolato M, Carullo G, Cione E, Aiello F, Caroleo MC. From the hive: Honey, a novel weapon against cancer. Eur J Med Chem. 2017;142:290-299. doi:10.1016/j.ejmech.2017.07.064

4. Mozherenkov VP, Prokof'eva GL. Apitherapy in ophthalmology. Oftalmol Zh. 1986;(5):314-316.

5. Masterov GD, Nersesian ON. Rol' apiterapii v kompleksnom lechenii bol'nykh khronicheskimi nespetsificheskimi zabolevaniiami legkikh [The role of apitherapy in the combined treatment of patients with chronic nonspecific lung diseases]. Lik Sprava. 1995;(3-4):155-158.

6. Zarobkiewicz MK, Wo?niakowski MM, S?awi?ski MA, Wawryk-Gawda E, Jod?owska-J?drych B. Bee pollen in allergy and immunology. Short review. Herba Pol [Internet]. 2017 Jan 1 [cited 2017 Jun 24];63(1). Available from: http://www.degruyter.com/view/j/hepo.2017.63.issue-1/hepo-2017-0007/hepo-20170007.xml

7. Eraslan G, Kanbur M, Silici S. Effect of carbaryl on some biochemical changes in rats: The ameliorative effect of bee pollen. Food Chem Toxicol. 2009 Jan;47(1):86-91.

8. Nagai T, Nagashima T, Myoda T, Inoue R. Preparation and functional properties of extracts from bee bread. Nahrung/Food. 2004 Jun;48(3):226-9.

9. Abouda Z, Zerdani I, Kalalou I, Faid M, Ahami MT. The Antibacterial Activity of Moroccan Bee Bread and Bee-Pollen (Fresh and Dried) against Pathogenic Bacteria. Res J Microbiol. 2011 Apr 1;6(4):376-84.

10. Markiewicz-Żukowska R, Naliwajko SK, Bartosiuk E, Moskwa J, Isidorov V, Soroczyńska J, et al. Chemical composition and antioxidant activity of beebread, and its influence on the glioblastoma cell line (U87MG). J Apic Sci [Internet]. 2013 Jan 1 [cited 2017 Jun 24];57(2). Available from: http://www.degruyter.com/view/j/jas.2013.57.issue-2/jas-2013-0025/jas-20130025.xml

11. Komosinska-Vassev K, Olczyk P, Ka?mierczak J, Mencner L, Olczyk K. Bee Pollen: Chemical Composition and Therapeutic Application. Evid Based Complement Alternat Med. 2015;2015:1-6. 
12. Akiyasu T, Paudyal B, Paudyal P, Kumiko M, Kazue U, Takuji N, et al. A Case Report of Acute Renal Failure Associated With Bee Pollen Contained in Nutritional Supplements. Ther Apher Dial. 2010 Feb;14(1):93-7.

13. Usta Güc B, Asilsoy S, Canan O, Kayaselcuk F. Does bee pollen cause to eosinophilic gastroenteropathy? Türk Pediatri Arş. 2015 Sep 3;50(3):189-92.

14. Güç BU, Asilsoy S, Canan O, Kayaselçuk F. Does bee pollen cause to eosinophilic gastroenteropathy? Turk Pediatri Ars. 2015;50(3):189-92.

15. Tsiapara AV, Jaakkola M, Chinou I, Graikou K, Tolonen T, Virtanen V, et al. Bioactivity of Greek honey extracts on breast cancer (MCF-7), prostate cancer (PC-3) and endometrial cancer (Ishikawa) cells: Profile analysis of extracts. Food Chem. 2009 Oct;116(3):702-8.

16. Li S. Antitumor activity of bee pollen polysaccharides from Rosa rugosa. Mol Med Rep [Internet]. 2013 Mar 20 [cited 2017 Apr 3]; Available from: http://www.spandidos-publications.com/10.3892/mmr.2013.1382

17. Almeida-Muradian LB, Pamplona LC, Coimbra S, Barth OM. Chemical composition and botanical evaluation of dried bee pollen pellets. J Food Compos Anal. 2005 Feb;18(1):105-11.

18. Wu Y-D, Lou Y-J. A steroid fraction of chloroform extract from bee pollen of Brassica campestris induces apoptosis in human prostate cancer PC-3 cells: BEE POLLEN OF BRASSICA CAMPESTRIS ON APOPTOSIS. Phytother Res. 2007 Nov;21(11):1087-91.

19. Graikou K, Kapeta S, Aligiannis N, Sotiroudis G, Chondrogianni N, Gonos E, et al. Chemical analysis of Greek pollen - Antioxidant, antimicrobial and proteasome activation properties. Chem Cent J [Internet]. 2011 Dec [cited 2017 Sep 16];5(1). Available from: http://ccj.springeropen.com/articles/10.1186/1752-153X-5-33

20. Yang, Kai; Wu, Dan; Ye, Xingqian; Liu, Donghong; Chen, Jianchu; Sun, Peilong (2013-01-23). "Characterization of Chemical Composition of Bee Pollen in China". Journal of Agricultural and Food Chemistry 